\title{
Relationship between vitamin D receptor gene polymorphisms, cardiovascular risk factors and adiponectin in a healthy young population
}

\begin{abstract}
Aim: To explore the association between VDR polymorphisms and several cardiovascular risk factors and adiponectin. Materials \& methods: Three-hundred and sixty-nine healthy students were randomly selected. Five VDR polymorphisms were genotyped: Bsml rs1544410; Cdx2 rs11568820; Apal rs7975232; Taql rs731236 and Fokl rs2228570. BMI, waist circumference (WC), blood pressure, lipid/glycemic profiles and adiponectin were assessed. Results: In men, Bsml, Apal and Taql were associated with BMI and WC $(p<0.05)$. Fokl was associated with triglycerides and high-density lipoprotein levels $(p=0.0036 ; p=0.005)$ whereas $B s m l$ and $C d \times 2$ were associated with adiponectin levels $(p=0.026 ; p=0.048)$. Associations disappeared after BMI and WC adjustments. In women, Apal was associated with systolic blood pressure $(p=0.02)$. Conclusion: Our study demonstrated a gender-specific difference between VDR SNPs and various cardiovascular risk factors and adiponectin.
\end{abstract}

First draft submitted: 16 March 2016; Accepted for publication: 10 June 2016; Published online: 27 September 2016

Keywords: adiponectin $\bullet$ cardiovascular risk factors $\bullet$ healthy subjects $\bullet$ VDR polymorphism - vitamin D

Vitamin D plays a central role in a large variety of metabolic pathways. It exerts its action at a cellular level through binding of the active metabolite 1,25-dihydroxyvitamin $\mathrm{D}$ to the vitamin D receptor (VDR). The VDR is expressed in many different cell types such as pancreatic $\beta$ cells, vascular smooth muscle cells, adipocytes, osteoblasts and chondrocytes $[1,2]$. It regulates more than $3 \%$ of the human genome, including genes that are crucial for glucose metabolism [3]. This finding probably explains the nonskeletal effects of vitamin D [3].

The gene encoding the VDR is located in the long arm of chromosome 12 (locus 12q12-q14) [4]. A large number of polymorphisms have been described so far in $V D R[4,5]$. Five SNPs of $V D R$ named $C d x 2$, FokI, BsmI, ApaI and TaqI, have been studied and were found to be related to bone characteristics and risk of fractures, although results remain equivocal [6,7]. Beside their effects on bone metabolism, VDR SNPs have been associated with cardiovascular (CV) diseases [8], metabolic syndrome (MS), increased risk of Type 2 diabetes [9,10], insulin resistance [11-13], unfavorable lipid profile [11-13], increased blood pressure [14], obesity [11] and mortality [15]. However, in each of these studies, few $V D R$ SNPs were analyzed in relation to $\mathrm{CV}$ risk factors. In addition, their relationship with adiponectin, an adipocyte specific protein with anti-atherogenic and insulin enhancer effects [16], has never been explored.

In Middle Eastern countries, more particularly in Lebanon [17,18] and Jordan [19], few studies looked at $V D R$ SNPs. These studies analyzed only two or three VDR SNPs (BsmI, TaqI and $A p a I$ ) and were limited to bone density measurement.

The main objective of this study is to assess whether five different $V D R$ SNPs
Aline Hajj', Rima Chedid², Eliane Chouery 2,3, André Megarbané2,3 \& Marie-Hélène Gannagé-Yared*,3,4

'Laboratoire de Pharmacologie, Pharmacie clinique et Contrôle de Qualité des médicaments, Pôle Technologie- Santé (PTS), Faculty of Pharmacy, Saint-Joseph University, Beirut, Lebanon

${ }^{2}$ Genetics Medical Unit, Faculty of Medicine, Saint-Joseph University, Beirut, Lebanon

${ }^{3}$ Faculty of Medicine, Saint-Joseph University, Beirut, Lebanon ${ }^{4}$ Department of Endocrinology, Hotel-Dieu de France Hospital, Saint-Joseph University, Beirut, Lebanon *Author for correspondence: Tel.: +961 3291301 Fax: +961 1615295 mariehelene.yared@usj.edu.lb 
(BsmI rs1544410; ApaI rs7975232 both in intron 8, Cdx2 rs11568820; TaqI rs731236 in exon 9 and FokI rs2228570 in exon 2) are associated with 25-hydroxyvitamin D (25[OH]D) levels, CV risk factors (mainly, body mass index [BMI], waist circumference [WC], blood pressure [BP], lipid and glycemic profiles) as well as adiponectin in a cohort of 369 young Lebanese men and women between 18 and 30 years of age.

\section{Material \& methods \\ Participants}

Participants are students from the Saint-Joseph University Medical Sciences Campus, located in Beirut, Lebanon. This cohort has been recruited as previously published [20]. Briefly, 369 randomly selected students of both genders accepted to participate in the study. Population age ranged between 18 and 30 years. The study was approved by the University Ethical Committee (Reference number USJ 2011-13). Each participant gave a written and informed consent before enrollment. Exclusion criteria were pregnancy, use of contraceptive pills or drugs that may affect lipid profile and/or metabolic parameters. In addition, none of the students were taking vitamin D supplements.

The following anthropometric measures, performed using the same devices throughout this study, were taken by a registered nurse: height in meters $(\mathrm{m})$, weight in kilograms $(\mathrm{kg})$ using a manual scale and WC, taken at the umbilicus, in $\mathrm{cm}$. Systolic BP (SBP) and diastolic BP (DBP) were measured in seated subjects after a rest for at least 15 min using a mercury tensiometer. BMI was calculated as weight $(\mathrm{kg}) /$ height $\left(\mathrm{m}^{2}\right)$.

\section{Biological parameters}

Blood was collected after a 12-h fasting period and across all seasons. In the hour following blood withdrawal, samples were centrifuged and serum was divided in several aliquots: some were stored at $-80^{\circ} \mathrm{C}$ for later insulin, adiponectin and $25(\mathrm{OH}) \mathrm{D}$ measurements and others were sent for biochemical analysis.

Fasting insulin was measured using a commercial chemiluminescent assay (Immulite, DPC, CA, USA). The assay sensitivity for insulin was $2 \mathrm{mIU} / \mathrm{ml}$ with intra-assay CVs below 9\%. Adiponectin was measured using a commercially available RIA kit (Linco Research, Inc., MO, USA). The assay sensitivity was $1 \mathrm{ng} / \mathrm{ml}$ and intraassay CV $<9.5 \%$. Insulin resistance was calculated using the homeostasis model assessment of insulin resistance (HOMA index), defined as (fasting immunoreactive insulin in $\mathrm{mU} / \mathrm{l} \times \mathrm{FPG}$ in $\mathrm{mmol} / \mathrm{L}) / 22.5$ [21]. The $25(\mathrm{OH}) \mathrm{D}$ was measured using the Dia Sorin radioimmunoassay (MN, USA). The assay sensitivity was $1.5 \mathrm{ng} / \mathrm{ml}$ and the CV was below $12 \%$. Biochemical parameters (glucose, total cholesterol, triglycerides and high-density lipoprotein [HDL] cholesterol) were measured using an automated COBAS Integra 400, Roche Diagnostics. Low-density lipoprotein (LDL)-cholesterol was then calculated using the Friedwald equation.

For all biological parameters measures, at least two levels of control were added systematically to every run.

\section{DNA isolation \& genotyping}

For DNA sampling, blood was collected on EDTA tubes and white cells were isolated using a lysis solution blood lymphocyte buffer containing $\mathrm{NH}_{4} \mathrm{Cl}, \mathrm{KHCO}_{3}$ and EDTA, and then frozen at $-80^{\circ} \mathrm{C}$.

Genomic DNA was extracted from $50 \mu \mathrm{l}$ buffy coat samples by standard salt-precipitation methods.

\section{RFLP-PCR genotyping}

PCR were performed in a final volume of $50 \mu \mathrm{l}$ containing approximately $100 \mathrm{ng}$ of DNA, $0.25 \mathrm{mM}$ dNTPs, $1.5 \mathrm{mM} \mathrm{MgCl} 2,100$ ng of each primer, $1 \times$ PCR buffer and $0.02 \mathrm{U}$ TaqDNA polymerase (Invitrogen Life Technologies, CA, USA). The amplification conditions for each PCR were $95^{\circ} \mathrm{C}$ for $5 \mathrm{~min}$, followed by 35 cycles of: $95^{\circ} \mathrm{C}$ for $60 \mathrm{~s}, 55^{\circ} \mathrm{C}$ for $60 \mathrm{~s}$ and $72^{\circ} \mathrm{C}$ for $60 \mathrm{~s}$, with a postcycling final extension of $10 \mathrm{~min}$ at $72^{\circ} \mathrm{C}$.

Primers used for the amplification of ApaI, BsmI and $C d x 2$ SNPs, were designed using Primer 3 [22] and checked for specificity using Basic Local Alignment Search Tool (BLAST) [23]. DNA sequences were obtained from UCSC or Genbank databases. Primers used for the study of FokI and TaqI SNPs were the same as those used respectively by Harris et al. [24] and

\begin{tabular}{|c|c|c|c|}
\hline Studied polymorphisms & Forward primer & Reverse primer & Product size \\
\hline$B s m I(r s 1544410)$ & $5^{\prime}$-cctcactgcccttagctctg-3' & 5'-tgcctccaaaatcaatcagg-3' & $247 \mathrm{bp}$ \\
\hline$C d \times 2(\mathrm{rs} 11568820)$ & 5'-ggatcccaaaaggaaaggaa-3' & 5'-tgttccagatggtaaaaatagaatga-3' & $396 \mathrm{bp}$ \\
\hline Apal (rs7975232) & 5'-ggatcctaaatgcacggaga-3' & 5'-acgtctgcagtgtgttggac-3' & $265 \mathrm{bp}$ \\
\hline Taql (rs731236) & 5'-cagagcatggacagggagcaa-3' & 5'-cacttcgagcacaagggggcgttagc-3' & $501 \mathrm{bp}$ \\
\hline Fokl (rs2228570) & $5^{\prime}$-agctggecctggcactgactctggctct-3' & $5^{\prime}$-atggaaacaccttgcttcttctccgtc-3' & $267 \mathrm{bp}$ \\
\hline
\end{tabular}




\begin{tabular}{|c|c|c|c|c|}
\hline Clinical and biological data & Total $(n=369)$ & Men $(n=192)$ & Women $(n=177)$ & p-value \\
\hline \multicolumn{5}{|l|}{ Clinical data } \\
\hline Age (years) & $23.9 \pm 4.0$ & $24.1 \pm 4.0$ & $23.8 \pm 4.0$ & 0.388 \\
\hline BMI $\left(\mathrm{kg} / \mathrm{m}^{2}\right)$ & $23.9 \pm 4.2$ & $25.6 \pm 4.1$ & $22.0 \pm 3.3$ & $<0.001 *$ \\
\hline Waist circumference $(\mathrm{cm})$ & $82.7 \pm 12.4$ & $89.8 \pm 11.0$ & $74.9 \pm 8.4$ & $<0.001 *$ \\
\hline Systolic blood pressure $(\mathrm{mmHg})$ & $110.7 \pm 13.1$ & $117.3 \pm 9.8$ & $103.4 \pm 12.3$ & $<0.001 *$ \\
\hline Diastolic blood pressure $(\mathrm{mmHg})$ & $70.6 \pm 9.8$ & $74.5 \pm 8.8$ & $66.4 \pm 9.1$ & $<0.001 *$ \\
\hline \multicolumn{5}{|l|}{ Biological data } \\
\hline $25(\mathrm{OH}) \mathrm{D}(\mathrm{ng} / \mathrm{ml})$ & $31.0 \pm 12.5$ & $29.2 \pm 11.3$ & $33.0 \pm 13.4$ & $0.003 *$ \\
\hline Fasting plasma glucose (mmol/L) & $4.87 \pm 0.3$ & $4.9 \pm 0.28$ & $4.8 \pm 0.23$ & $<0.001 *$ \\
\hline Insulin (mIU/ml) & $9.2 \pm 4.9$ & $9.7 \pm 5.2$ & $8.5 \pm 4.5$ & $0.017 *$ \\
\hline HOMA index & $2.0 \pm 1.1$ & $2.1 \pm 1.2$ & $1.8 \pm 1.0$ & $0.006^{*}$ \\
\hline Adiponectin $(\mu \mathrm{g} / \mathrm{ml})$ & $11.6 \pm 6.3$ & $8.2 \pm 4.1$ & $15.3 \pm 6.2$ & $<0.001 *$ \\
\hline Triglycerides (mmol/L) & $1.06 \pm 0.7$ & $1.20 \pm 0.85$ & $0.89 \pm 0.55$ & $<0.001 *$ \\
\hline HDL cholesterol (mmol/L) & $1.23 \pm 0.3$ & $1.13 \pm 0.27$ & $1.34 \pm 0.31$ & $<0.001 *$ \\
\hline Total cholesterol (mmol/L) & $4.57 \pm 1.0$ & $4.54 \pm 0.99$ & $4.61 \pm 1.09$ & 0.461 \\
\hline LDL cholesterol (mmol/L) & $2.87 \pm 1.0$ & $2.88 \pm 0.99$ & $2.86 \pm 1.05$ & 0.851 \\
\hline
\end{tabular}

Riggs et al. [25]. All primer sequences and product sizes are listed in Table 1.

The PCR products were verified using 1\% agarose gel containing SYBR ${ }^{\circledR}$ Safe (Life Technologies, CA, USA). $15 \mu \mathrm{l}$ of each PCR were digested with 7.5 unit of each restriction enzyme (New England Biolabs, Inc., MA, USA) and incubated overnight at $25^{\circ} \mathrm{C}$ for ApaI, at $37^{\circ} \mathrm{C}$ for BsmI, HpyCH4III (Cdx2) and FokI, and for $3 \mathrm{~h}$ at $65^{\circ} \mathrm{C}$ for TaqI. $20 \mu \mathrm{l}$ of each digested reaction mixture were then loaded and separated into $2 \%$ agarose gel.
Bsml polymorphism

The GG genotype shows only two bands of 144 and 103 bp. The AA genotype displays one fragment of $247 \mathrm{bp}$. The heterozygote displays three fragments of 247, 144 and 103 bp.

\section{Cdx2 polymorphism (HpyCH4III)}

The GG genotype shows three bands of 265, 80 and $51 \mathrm{bp}$. The AA genotype yields two fragments of 316 and $80 \mathrm{bp}$. The heterozygote displays four fragments of $316,265,80$ and $51 \mathrm{bp}$.

Table 3. Genotype and allele frequencies of the studied SNPs.

\begin{tabular}{|c|c|c|c|c|c|c|c|c|c|c|}
\hline \multirow[t]{2}{*}{ Gene } & & \multirow[t]{2}{*}{ dbSNP } & \multirow{2}{*}{$\begin{array}{l}\text { Alleles } \\
(\mathrm{B} / \mathrm{b})^{\dagger}\end{array}$} & \multirow{2}{*}{$\begin{array}{l}\text { Patients } \\
\text { (n) }\end{array}$} & \multicolumn{5}{|c|}{ Subjects (n) } & \multirow[t]{2}{*}{$p$-value } \\
\hline & & & & & BB & $\mathrm{Bb}$ & bb & B & b & \\
\hline$V D R$ & $C d x 2$ & rs11568820 & G/A & 350 & $246(70.3)$ & $89(25.4)$ & $15(4.3)$ & 0.83 & 0.17 & 0.194 \\
\hline$V D R$ & Apal & rs7975232 & $\mathrm{T} / \mathrm{G}$ & 369 & $128(34.7)$ & $178(48.2)$ & $63(17.1)$ & 0.59 & 0.41 & 0.998 \\
\hline VDR & Fokl & rs2228570 & $F / f^{\oplus}$ & 369 & $209(56.6)$ & $146(39.6)$ & $14(3.8)$ & 0.76 & 0.24 & 0.161 \\
\hline
\end{tabular}




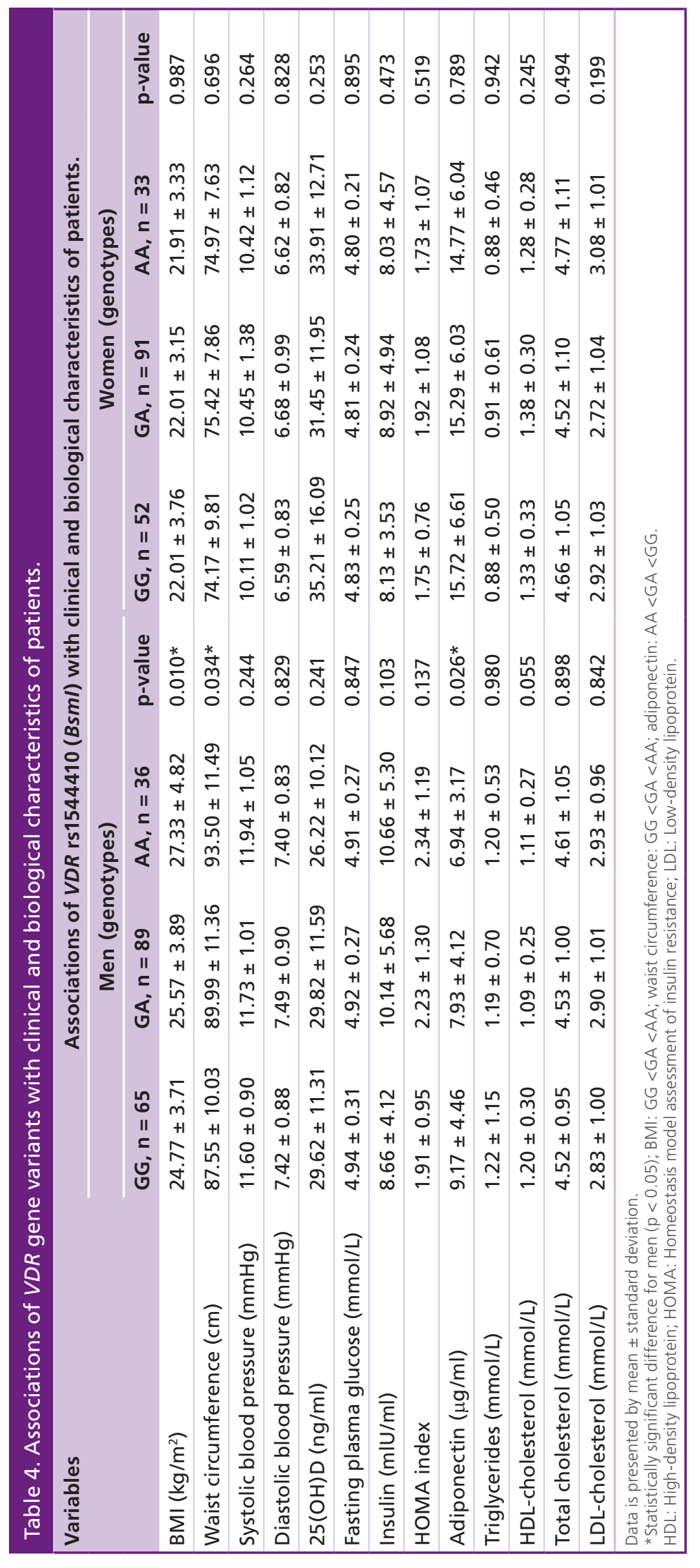

Apal polymorphism

The TT genotype lacks an ApaI site and shows only one band of $265 \mathrm{bp}$. The GG genotype generates two fragments of 146 and $119 \mathrm{bp}$. The heterozygote displays three fragments of 265, 146 and $119 \mathrm{bp}$, designated as TG.

\section{Taql polymorphism}

TaqI digestion revealed one obligatory restriction site, the homozygous TT (absence of the specific TaqI restriction site) yielded bands of 495 and $6 \mathrm{bp}$. The homozygous CC exhibited 294, 201, 6 bp and the heterozygous CT provided gave 495, 294, 201, 6 bp fragments.

\section{Fokl polymorphism}

The AA, CC and GG genotypes (noted FF) lack a FokI site and shows only one band of $267 \mathrm{bp}$. The TT genotype (noted ff) yields two fragments of 195 and $72 \mathrm{bp}$. The heterozygote displays three fragments of 267,195 and $72 \mathrm{bp}$ corresponding to AT, CT or GT (all noted Ff).

\section{DNA sequencing}

Positive heterozygous and homozygous controls (defined by direct sequencing) and negative controls (water) were systematically included in experiments. In addition, genotypes of some randomly selected subjects were confirmed by Sanger sequencing. PCR products were purified using the Illustra ${ }^{\circledR}$ GFX PCR DNA and Gel Band Purification Kit (GE Healthcare, Buckinghamshire, UK), and both strands of the obtained products were sequenced using the BigDye ${ }^{\circledR}$ Terminator v1.1 Cycle Sequencing Kit (Applied Biosystems, CA, USA) under standard conditions. The labeled products were subjected to electrophoresis on an ABI 3130 Genetic Analyzer sequencing system (Applied Biosystems). Electropherograms were analyzed using Sequence Analysis Software version 5.2 (Applied Biosystems) and compared with reference sequences using ChromasPro version 1.7.6.1 (Technelysium, Queensland, Australia).

\section{Statistical analysis}

Statistical analyses were performed using a software program (SPSS for Windows version 18.0, IL, USA). Descriptive statistics were used to describe clinical and biological data of the overall population. Chi-square $\left(\chi^{2}\right)$ test and Fisher Exact test were used to compare categorical variables among two or more groups. Variables were tested for normality distribution using the Kolmogorov-Smirnov test and equality of variance using the Levene test.

Student's $t$-tests were used to compare continuous variables between two groups. When the variables were not normally distributed, Mann-Whitney tests 
were done. Analyses of variance followed by Tukey post-hoc tests were used to compare continuous variables between three or more groups. When the variables were not normally distributed, KruskalWallis tests followed by Mann-Whitney tests were carried out. The associations between VDR SNPs and other variables were performed after adjustment for cofounding factors to ensure that these associations were not due to chance. A multivariate analysis was performed when needed, for BMI and WC adjustments.

Deviation from the Hardy-Weinberg equilibrium was tested using $\chi^{2}$ analysis.

Data were considered statistically significant if p-values were $<0.05$.

\section{Results}

\section{General characteristics of the studied population}

Three hundred and sixty nine randomly selected students (192 men and 177 women) out of 390 accepted to participate in the study. The participants mean age was $23.9 \pm 4$ years with a mean BMI of $23.9 \pm 4.2 \mathrm{~kg} / \mathrm{m}^{2}$. Table 2 summarizes the main clinical and biological data of the population. As shown, several studied values were significantly different between men and women.

\section{Genotype \& allele distribution}

Results of genotyping and allele distribution are summarized in Table 3. The whole population as well as subpopulations (men and women) were in Hardy-Weinberg equilibrium for all SNPs ( $\mathrm{p}$-values for the whole population are presented in Table 3; $\mathrm{p}$-values for subpopulations are presented in Supplementary Table 1). In addition, no statistical differences for genotype distribution between men and women were observed (Supplementary Table 1).

\section{Relation between VDR genotypes, 25(OH)D} and metabolic parameters

To explore the association between VDR SNPs and the different clinical and biological parameters, we performed the analyses separately for men and women taking into account the statistical differences obtained between the two groups (as shown in Table 1). Results are presented in Tables 4-8.

\section{Association between VDR SNPs \& 25(OH)D levels}

Among all the studied SNPs, only ApaI was associated with $25(\mathrm{OH}) \mathrm{D}$ levels in both men and women. Students with the TT genotype for $V D R$ T $>\mathrm{G}$ had significantly lower $25(\mathrm{OH}) \mathrm{D}$ levels than GG students (respective p-values for men and women are 0.019 and 0.024; Table 6).

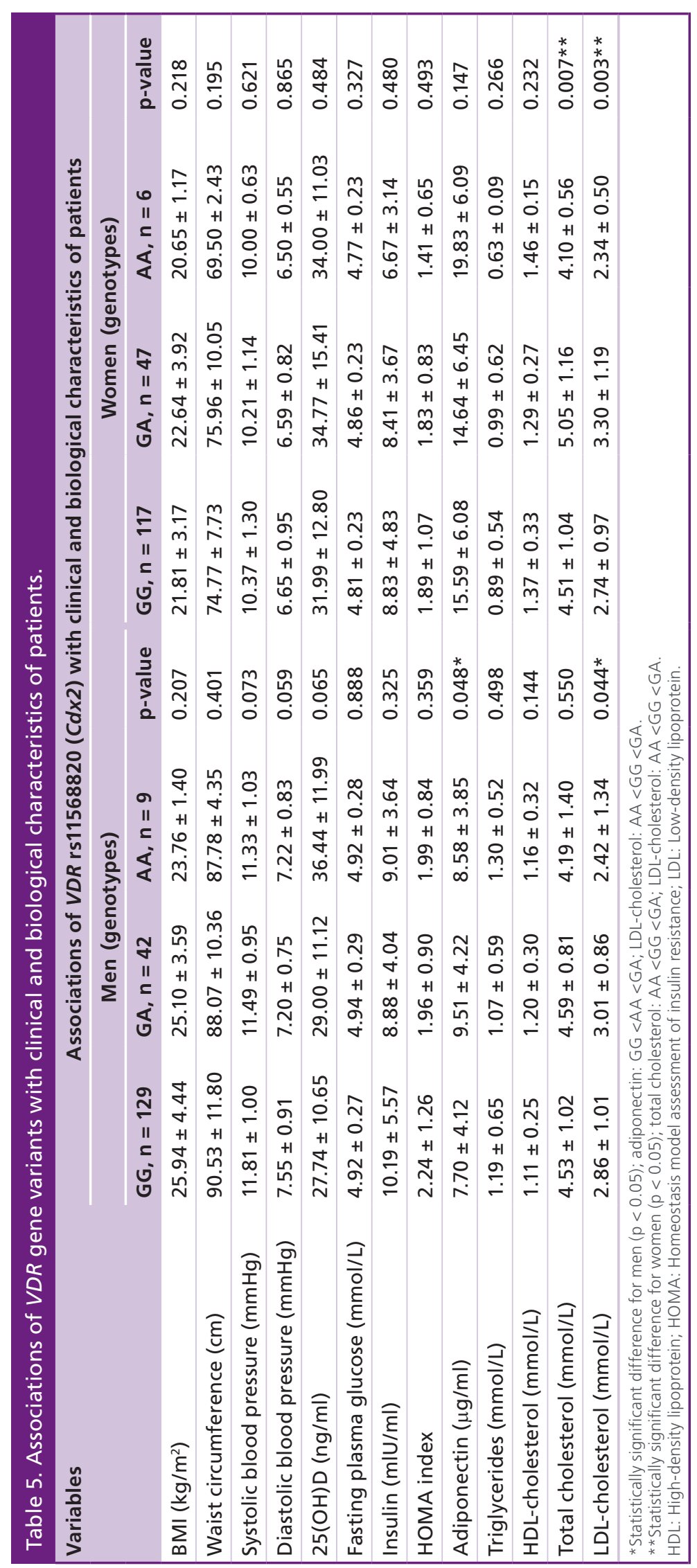




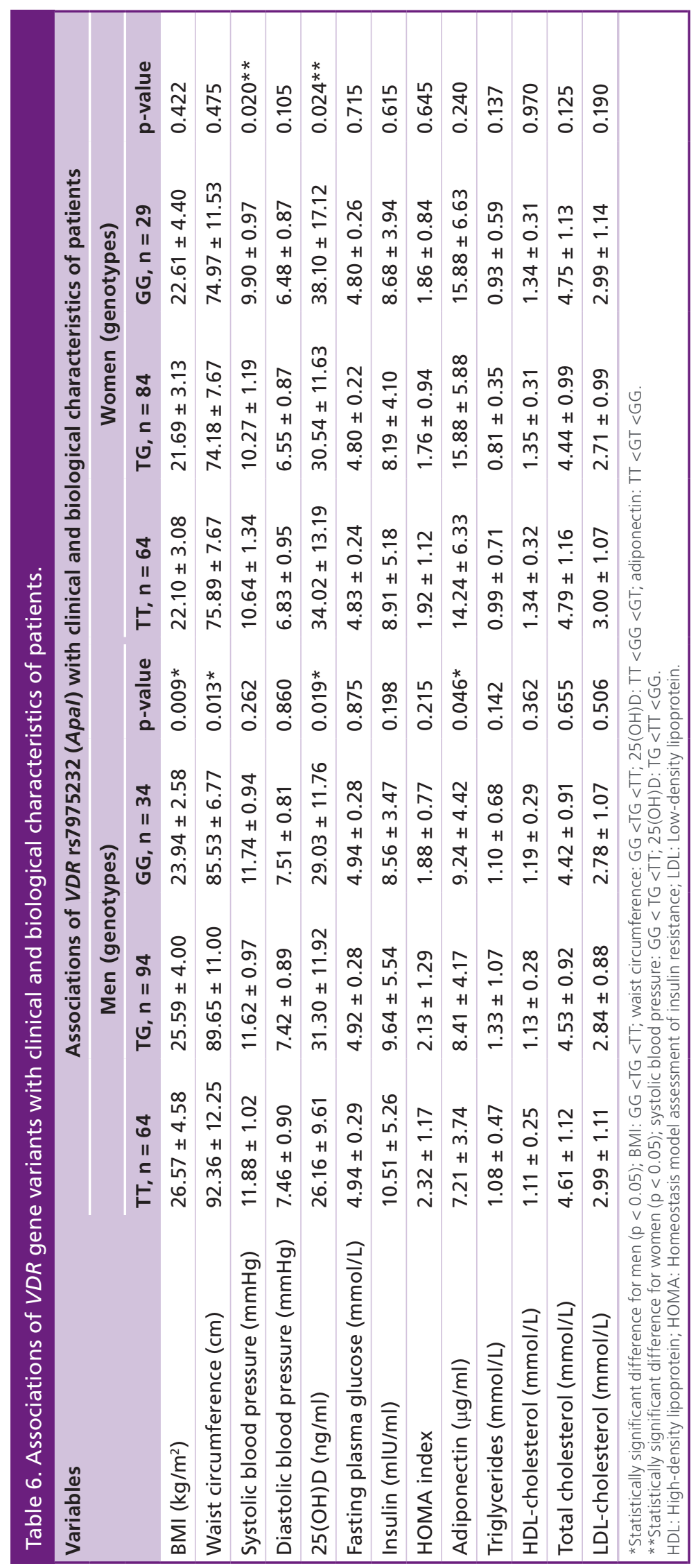

Association between VDR SNPs \& BP

In women, higher SBP was noted with the TT genotype for ApaI (T>G) (Table 6). No significant differences were observed in men.

\section{Association between VDR SNPs \& metabolic parameters \\ Association with BMI \& WC}

In men, students carrying the AA genotype for BsmI (G>A), TT genotype for ApaI (T>G) and CC genotype for TaqI $(\mathrm{T}>\mathrm{C})$ had higher BMI and WC compared with those with other genotypes (for BMI, respective p-values for BsmI, ApaI and TaqI are 0.01, 0.009 and 0.003; for WC, respective p-values are 0.034, 0.013 and 0.009 ; Tables 4, $6 \&$ 7). No significant associations were observed in women.

Association with lipid profile (total cholesterol, LDL-cholesterol, HDL-cholesterol \& triglycerides) In both men and women, VDR FokI and $C d x 2$ were associated with the lipid profile. Among men, FF carriers of the FokI (F>f) SNP had significantly higher triglycerides and lower HDL-cholesterol levels than Ff or ff carriers ( $p=0.036$ and 0.005 respectively; Table 8). In women, students carrying at least one $\mathrm{f}$ allele had significantly higher cholesterol levels (total cholesterol and LDLcholesterol) than FF carriers ( $\mathrm{p}=0.028$ and 0.033 respectively). On the other hand, for the $C d x 2(\mathrm{G}>\mathrm{A}) \mathrm{SNP}$, male and female students with at least one G allele (GG or GA) had significantly higher LDL-cholesterol compared with the AA students (respectively $\mathrm{p}=0.044$ and $\mathrm{p}=0.003$ ); while for the total cholesterol, this difference was only significant in women ( $p=0.007)$ (Table 5).

\section{Association with glycemic profile (fasting plasma} glucose, insulin, HOMA index)

Among the different studied SNPs, only the VDR TaqI (T>C) was associated with insulin levels: male students carrying the CC genotype had significantly higher insulin levels than the other groups $(p=0.046$; Table 7). This association disappeared after adjustment for both BMI and WC $(p=0.52)$. None of the studied SNPs was related to fasting plasma glucose or HOMA index in both men and women.

\section{Association with adiponectin}

In men, both $\operatorname{VDR} B \operatorname{sim} I(\mathrm{G}>\mathrm{A})$ and $C d x 2(\mathrm{G}>\mathrm{A})$ were associated with adiponectin levels: students with the AA genotype for BsmI and GG for $C d x 2$ had significantly lower adiponectin levels than other genotypes ( $\mathrm{p}=0.026$ and 0.048 respectively; Tables 4 \& 5). These associations disappeared after adjustment for both BMI and WC (respectively $\mathrm{p}=0.08$ and $\mathrm{p}=0.35$ for $B s m I$ and $C d x 2$ ). 


\section{Discussion}

This study assessed, in a Middle-Eastern cohort of young men and women aged 18-30 years, whether five VDR SNPs (BsmI, Cdx2, ApaI, TaqI, FokI) are associated with $25(\mathrm{OH}) \mathrm{D}$ levels, CV risk factors and adiponectin.

Our results showed that the ApaI $(\mathrm{T}>\mathrm{G})$ SNP was associated with $25(\mathrm{OH}) \mathrm{D}$ levels in both male and female students; subjects with the TT genotype showing significantly lower levels than those with the GG genotype. The relationship between VDR SNPs and bone biology has been largely studied in populations of different ethnic origins but studies were mainly performed on adults and in relation with bone density. The few studies that have been conducted in children and young people to investigate the influence of VDR SNPs on vitamin $\mathrm{D}$ levels have reported divergent results. Santos et al. [26] studied a group of Brazilian girls aged 7-18 years and found that $V D R$ wild-type genotypes for BsmI, ApaI and TaqI were significantly associated with lower $25(\mathrm{OH}) \mathrm{D}$ levels. Other authors did not find any association $[27,28]$. More studies are required to elucidate the contribution of $V D R$ genetic SNPs on serum $25(\mathrm{OH}) \mathrm{D}$ in healthy subjects. The exact molecular mechanism explaining the association between $V D R$ polymorphisms and $25(\mathrm{OH}) \mathrm{D}$ serum levels remains unknown. Levin et al. [15] speculate that greater VDR activity for a given amount of $25(\mathrm{OH}) \mathrm{D}$ could provide protection in situations of low $25(\mathrm{OH}) \mathrm{D}$ substrate.

We then found an association between ApaI ( $\mathrm{T}>\mathrm{G}$ ) genotype and $\mathrm{BP}$, female students with TT genotype having higher levels of SBP. These results are in line with the one reported for the BsmIVDRSNP in Korean workers [29]. In another study, an opposite relationship was shown [14] with the same SNP in healthy men and women. Finally, a recent large genetic study failed to reproduce any association between VDR related SNPs and $\mathrm{BP}$ [30], suggesting that further research is needed to elucidate these findings. Interestingly, in our study, the ApaITT genotype group, who has higher BP levels, shows also significantly lower $25(\mathrm{OH}) \mathrm{D}$ levels than the TG or GG groups, suggesting a clear link between vitamin $\mathrm{D}$ and $\mathrm{BP}$. Our findings may suggest that, at least in women, a common genetic polymorphism may predispose to both vitamin D deficiency and high BP. The link between vitamin $\mathrm{D}$ and hypertension may be explained through the calcium metabolism. In fact, it has been shown that calcium supplementation [31-33] and high vitamin $\mathrm{D}$ intake are associated with lower BP [34]. This link may also be explained through the renin-angiotensin system since $25(\mathrm{OH}) \mathrm{D}$ and the FokI SNP were independently associated with lower plasma renin activity in both hyper- and normo-tensive patients [35].

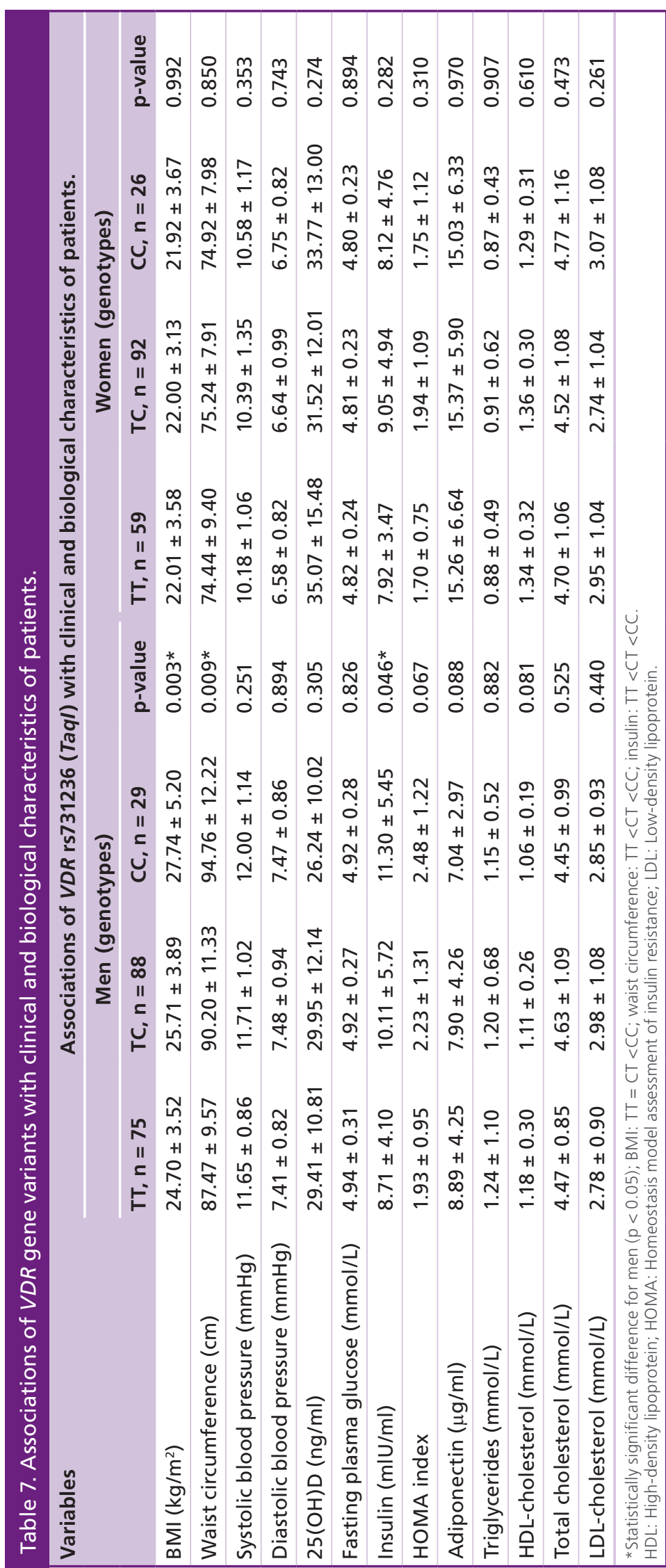




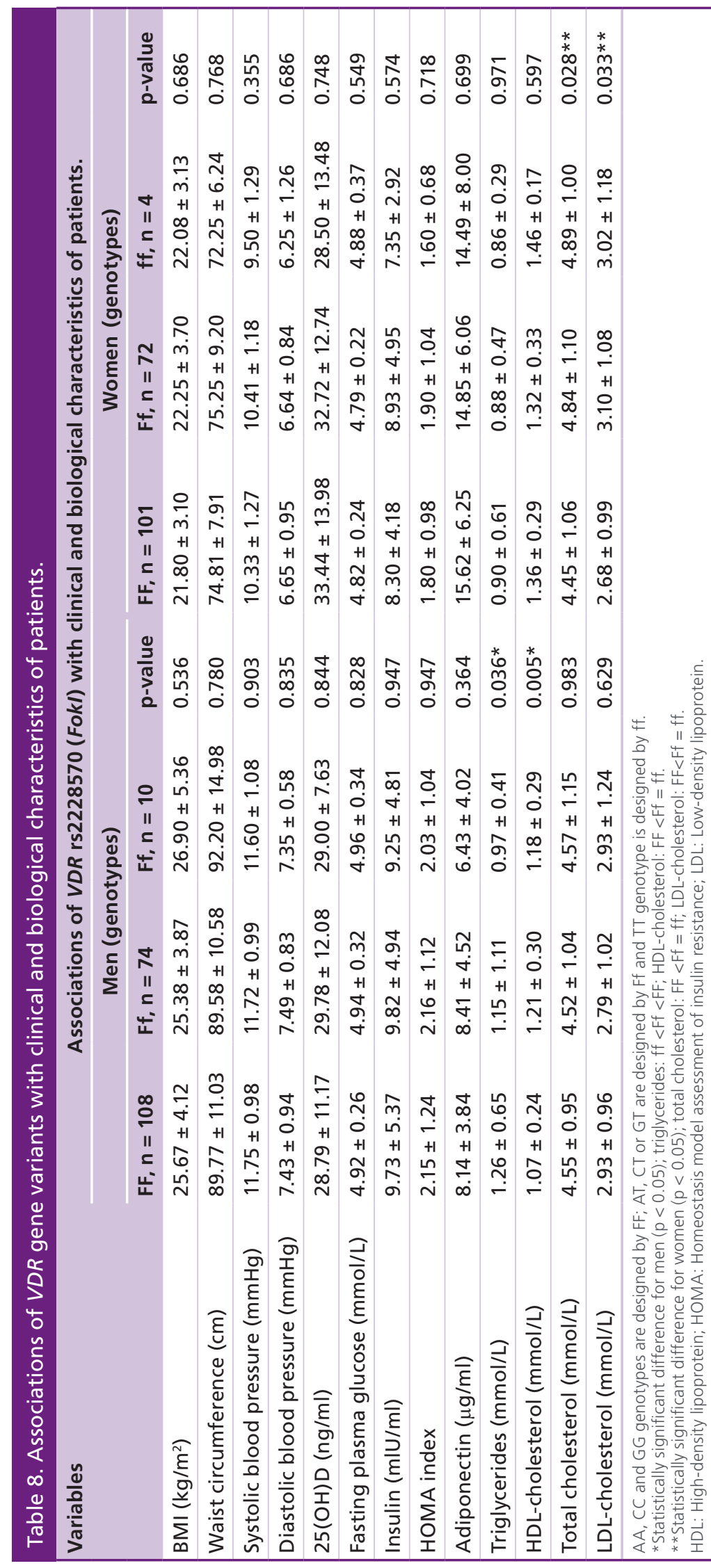

In addition, our results showed that the BsmI $(\mathrm{G}>\mathrm{A})$, ApaI $(\mathrm{T}>\mathrm{G})$ and TaqI $(\mathrm{T}>\mathrm{C})$ SNPs influenced BMI and WC in male students. These results suggest a strong genetic link between vitamin D and adiposity and are in agreement with two previously published studies $[11,36]$. Both studies - the first one, which was performed on 176 healthy Polish men [11] and the second one on 570 Saudi subjects [36] - showed that the presence of the minor allele A of $B s m I$ is positively associated with obesity. A third study highlighted that healthy women with AA genotype (for $B s m I$ ) were characterized by higher body weight and fat mass compared with those carrying the GG genotype [37].

Importantly, we identified a relationship between VDR SNPs (FokI; $\mathrm{F}>\mathrm{f}$ and $C d x 2 ; \mathrm{G}>\mathrm{A}$ ) and lipid profile. In men, FF carriers for the FokI SNP displayed significantly higher triglycerides and lower HDL-levels than $\mathrm{Ff}$ or ff carriers; whereas, women carrying at least one $f$ allele had significantly higher total and LDLcholesterol. Our results are in line with two previously reported studies. The first one showed, in 176 healthy men, that FF carriers for FokI SNP had significantly lower HDL-cholesterol levels compared with the other groups [11]. While the second one showed that the FokI variant was associated with cholesterol levels in subjects with ischemic stroke [38]. Other studies showed opposite results [13] or no associations with the FokI SNP [39]. As for $C d x 2$ SNP, we found that both male and female students with at least one $G$ allele had significantly higher LDL-cholesterol levels than AA students, a finding that has never been reported before. Several hypotheses could explain how the vitamin D-VDR axis affects lipid profile; vitamin D induces suppression of parathyroid hormone secretion which in turn reduces lipolysis [40]. In addition, vitamin D by increasing intestinal calcium absorption can lower hepatic triglycerides synthesis [41]. Finally, vitamin D may indirectly affect the lipid metabolism through improvement of insulin secretion and sensitivity [42].

The relation between VDR and glucose metabolism has been the subject of several publications. Some allelic variations in genes involved in vitamin $\mathrm{D}$ metabolism and VDR are associated with glucose (in)tolerance, insulin secretion and sensitivity [11-13,43]. In our study, no association was found between fasting plasma glucose or HOMA index and the VDR SNPs. Our results are in line with two other studies $[13,44]$. The absence of an obvious link with the glycemic components could be explained by the fact that our population is young and healthy.

The major new finding in our research is the association we found between two VDR SNPs ( $B s m I \mathrm{G}>\mathrm{A}$ and $C d \times 2 \mathrm{G}>\mathrm{A})$ and adiponectin levels in male stu- 
dents. However, after adjustment for BMI and WC, these associations disappeared. To the best of our knowledge, this is the first study looking at the association between adiponectin and VDR SNPs in a healthy population. Such association has only been previously described in women with polycystic ovary syndrome $[45,46]$, but not in normal healthy subjects. One hypothesis that could explain such relationship is that 1,25-dihydroxyvitamin D regulates the expression of adipokine in visceral fat, suggesting that vitamin $\mathrm{D}$ may upregulate the adiponectin gene [20]. Further studies are needed to clarify this association.

It is noteworthy to add that, in our study, the genetic associations between $V D R$ SNPs was gender specific, some differences being noted only in the male population, whereas others were obvious in both men and women. This could be due to sex-dependent regulating factors such as estrogen. In fact, cross-talks between estrogen and vitamin $\mathrm{D}$ endocrine system are well known. Estrogen has been shown to upregulate VDR expression in the duodenal mucosa and concurrently, it increases the responsiveness to endogenous 1,25-dihydroxyvitamin D [47]. Another explanation could be the less favorable metabolic profile of our male subjects as compared with females.

\section{Study strengths \& limitations}

We noted that when we compared our results to the literature, we faced some difficulties because of differences in the adopted genetic nomenclature and because of the lack of mention of the SNP ID references (or 'rs' ID) in most of the previously published studies. The strength of our study is that it includes the international updated SNP nomenclature, mentioning each time the ancestral and the mutated allele based on the
NCBI database [48]. In addition, we performed statistical analysis after adjustment for confounding factors, to ensure that these associations were not due to chance. However, some of the negative findings may be due to other confounders such as lifestyle (dietary, smoking, alcohol intake and exercise) that have not been evaluated in the present study. Another point that deserves to be pointed out in this article, is that most of the studied SNPs are nonfunctional, which probably explains the conflicting results in the literature. Therefore, it is assumed that one or more of these SNPs might be in linkage-disequilibrium with one or more truly functional SNPs affecting vitamin D pathways.

\section{Conclusion}

In conclusion, our study is the first to look at a large panel of $V D R$ SNPs in a relatively large cohort of young and healthy men and women. We identified several interesting associations between the studied $V D R$ SNPs and various metabolic parameters. These associations were gender-specific, the association with $\mathrm{BP}$ being predominant in women, while the association with the major MS parameters such as abdominal obesity, high triglycerides, low HDL-cholesterol and adiponectin were mainly observed in men. Since the allelic frequencies in our population were similar to those described in Caucasian populations (European HapMap control population, $\mathrm{n}=113$ [48]], we assume that the observed associations in our population can be extrapolated to other populations. As far as public health is concerned, it would be interesting to follow these young subjects over time in order to assess, relying on genotype, the effects of vitamin D supplementation or lifestyle on the development of CV risk factors and subsequently on CV diseases.

\section{Executive summary}

- Numerous studies have reported significant associations between VDR polymorphisms and cardiovascular (CV) risk factors but none of them has combined five different polymorphisms in relation with these risk factors and adiponectin in a young healthy population.

- Our study assessed the association between VDR polymorphisms (Bsml, Cdx2, Apal, Taql and Fokl) and several CV risk factors (BMI, waist circumference [WC], blood pressure, lipid and glycemic profiles) and adiponectin in a randomly selected cohort of 369 young Lebanese students.

- Our results showed that, in men, compared with other genotypes, the AA genotype for Bsml, TT genotype for Apal and CC genotype for Taql are associated with higher BMI and WC ( $p<0.05$ for all comparisons).

- In men, FF carriers of the Fokl ( $F>f)$ have higher triglycerides and lower HDL levels $(p=0.0036$ and $p=0.005)$ whereas the AA genotype for $B s m I(G>A)$ and $G G$ for $C d x 2(G>A)$ are associated with lower adiponectin levels $(p=0.026$ and $p=0.048)$. However, associations disappeared after BMI and WC adjustments.

- In women, the TT genotype for Apal (T>G) is associated with higher systolic BP $(p=0.02)$.

- In both men and women, the presence of at least one $\mathrm{G}$ allele for $\mathrm{Cd}$ x2 SNP is associated with higher low-density lipoprotein cholesterol ( $p=0.044$ in men and $p=0.003$ in women).

- None of the studied SNPs is related to fasting plasma glucose or homeostasis model assessment index.

- Our study demonstrated a gender-specific difference in the relation between VDR SNPs and various CV risk factors and adiponectin. Further studies are needed to confirm these findings. 


\section{Supplementary data}

To view the supplementary data that accompany this paper, please visit the journal website at:/www.futuremedicine.com/ doi/full/10.2217/pgs-2016-0045

\section{Author contributions}

A Hajj participated to the data analysis and was the main author contributing to the manuscript writing. $\mathrm{R}$ Chedid performed the sampling of the students. E Chouery and A Megarbané performed the genetic part of the study. M-H Gannagé-Yared designed the study, performed the laboratory analysis, collected the data and participated with A Hajj in the manuscript writing. All the authors approved the final version of the manuscript

\section{Financial \& competing interests disclosure}

This work was fully funded by a grant from the 'Conseil de la Recherche de I'Université Saint-Joseph' (FM213). The authors have no other relevant affiliations or financial involvement

\section{References}

Papers of special note have been highlighted as:

- of interest; $\bullet$ • of considerable interest

1 Ding C, Gao D, Wilding J, Trayhurn P, Bing C. Vitamin D signalling in adipose tissue. Br. J. Nutr. 108(11), 1915-1923 (2012).

2 Holick MF. Vitamin D deficiency. N. Engl. J. Med. 357(3), 266-281 (2007).

3 Rosen CJ, Adams JS, Bikle DD et al. The nonskeletal effects of vitamin D: an Endocrine Society scientific statement. Endocr. Rev. 33(3), 456-492 (2012).

4 Uitterlinden AG, Fang Y, Van Meurs JB, Pols HA, Van Leeuwen JP. Genetics and biology of vitamin D receptor polymorphisms. Gene 338(2), 143-156 (2004).

5 Fang Y, van Meurs JB, d'Alesio A et al. Promoter and 3 -untranslated-region haplotypes in the vitamin D receptor gene predispose to osteoporotic fracture: the Rotterdam Study. Am. J. Hum. Genet. 77(5), 807-823 (2005).

6 Casado-Diaz A, Cuenca-Acevedo R, Navarro-Valverde C et al. Vitamin D status and the $\mathrm{Cdx}-2$ polymorphism of the vitamin $\mathrm{D}$ receptor gene are determining factors of bone mineral density in young healthy postmenopausal women. J. Steroid Biochem. Mol. Biol. 136, 187-189 (2013).

7 Uitterlinden AG, Ralston SH, Brandi ML et al. The association between common vitamin $\mathrm{D}$ receptor gene variations and osteoporosis: a participant-level meta-analysis. Ann. Intern. Med. 145(4), 255-264 (2006).

8 Ferrarezi DA, Bellili-Munoz N, Dubois-Laforgue D et al. Allelic variations of the vitamin $\mathrm{D}$ receptor $(V D R)$ gene are associated with increased risk of coronary artery disease in Type 2 diabetics: the DIABHYCAR prospective study. Diabetes Metab. 39(3), 263-270 (2013).

- A recent large prospective study investigated the associations of $V D R$ gene variants with coronary artery disease in two cohorts of Type 2 diabetes patients (3137 subjects). with any organization or entity with a financial interest in or financial conflict with the subject matter or materials discussed in the manuscript apart from those disclosed.

No writing assistance was utilized in the production of this manuscript.

\section{Ethical conduct of research}

The authors state that they have obtained appropriate institutional review board approval or have followed the principles outlined in the Declaration of Helsinki for all human or animal experimental investigations. In addition, for investigations involving human subjects, informed consent has been obtained from the participants involved.

\section{Open access}

This work is licensed under the Attribution-NonCommercialNoDerivatives 4.0 Unported License. To view a copy of this license, visit http://creativecommons.org/licenses/by-nc-nd/4.0/

9 Oh JY, Barrett-Connor E. Association between vitamin D receptor polymorphism and Type 2 diabetes or metabolic syndrome in community-dwelling older adults: the Rancho Bernardo Study. Metabolism 51(3), 356-359 (2002).

10 Ortlepp JR, Lauscher J, Hoffmann R, Hanrath P, Joost HG. The vitamin $\mathrm{D}$ receptor gene variant is associated with the prevalence of Type 2 diabetes mellitus and coronary artery disease. Diabet. Med. 18(10), 842-845 (2001).

11 Filus A, Trzmiel A, Kuliczkowska-Plaksej J et al. Relationship between vitamin D receptor BsmI and FokI polymorphisms and anthropometric and biochemical parameters describing metabolic syndrome. Aging Male 11(3), 134-139 (2008).

12 Jain R, von Hurst PR, Stonehouse W, Love DR, Higgins $\mathrm{CM}$, Coad J. Association of vitamin D receptor gene polymorphisms with insulin resistance and response to vitamin D. Metabolism 61(3), 293-301 (2012).

- Demonstrated that the genotyping of the VDR gene may provide a predictive measure for insulin resistance in response to vitamin $\mathrm{D}$ intervention.

13 Schuch NJ, Garcia VC, Vivolo SR, Martini LA. Relationship between vitamin $\mathrm{D}$ receptor gene polymorphisms and the components of metabolic syndrome. Nutr. J. 12, 96 (2013).

14 Muray S, Parisi E, Cardus A, Craver L, Fernandez E. Influence of vitamin $\mathrm{D}$ receptor gene polymorphisms and 25-hydroxyvitamin $\mathrm{D}$ on blood pressure in apparently healthy subjects. J. Hypertens. 21(11), 2069-2075 (2003).

15 Levin GP, Robinson-Cohen C, de Boer IH et al. Genetic variants and associations of 25 -hydroxyvitamin $\mathrm{D}$ concentrations with major clinical outcomes. JAMA 308(18), 1898-1905 (2012).

- A large community-based Cardiovascular Health Study assessing genetic variants and associations of 25-hydroxyvitamin D concentrations with major clinical outcomes.

16 Lihn AS, Pedersen SB, Richelsen B. Adiponectin: action, regulation and association to insulin sensitivity. Obes. Rev. 6(1), 13-21 (2005). 
17 Arabi A, Mahfoud Z, Zahed L, El-Onsi L, El-Hajj Fuleihan G. Effect of age, gender and calciotropic hormones on the relationship between vitamin $\mathrm{D}$ receptor gene polymorphisms and bone mineral density. Eur. J. Clin. Nutr. 64(4), 383-391 (2010).

18 Arabi A, Zahed L, Mahfoud Z et al. Vitamin D receptor gene polymorphisms modulate the skeletal response to vitamin D supplementation in healthy girls. Bone 45(6), 1091-1097 (2009).

19 Kanan RM. The effect of FokI vitamin D receptor polymorphism on bone mineral density in Jordanian perimenopausal women. Indian J. Hum. Genet. 19(2), 233-238 (2013).

20 Gannage-Yared MH, Chedid R, Khalife S, Azzi E, Zoghbi F, Halaby G. Vitamin D in relation to metabolic risk factors, insulin sensitivity and adiponectin in a young Middle-Eastern population. Eur. J. Endocrinol. 160(6), 965-971 (2009).

- The first study describing a positive association between $25(\mathrm{OH}) \mathrm{D}$ and adiponectin.

21 Vaccaro O, Masulli M, Cuomo V et al. Comparative evaluation of simple indices of insulin resistance. Metabolism 53(12), 1522-1526 (2004).

22 Primer3 v. 0.4.0. http://frodo.wi.mit.edu

23 National Center for Biotechnology Information. http://blast.ncbi.nlm.nih.gov/Blast.cgi

24 Harris SS, Eccleshall TR, Gross C, Dawson-Hughes B, Feldman D. The vitamin D receptor start codon polymorphism $(F o k I)$ and bone mineral density in premenopausal American black and white women. J. Bone Miner. Res. 12(7), 1043-1048 (1997).

25 Riggs BL, Nguyen TV, Melton LJ 3rd et al. The contribution of vitamin $\mathrm{D}$ receptor gene alleles to the determination of bone mineral density in normal and osteoporotic women. J. Bone Miner. Res. 10(6), 991-996 (1995).

26 Santos BR, Mascarenhas LP, Satler F, Boguszewski MC, Spritzer PM. Vitamin D deficiency in girls from south Brazil: a cross-sectional study on prevalence and association with vitamin D receptor gene variants. BMC Pediatr. 12, 62 (2012).

27 Valtuena J, Gonzalez-Gross M, Huybrechts I et al. Factors associated with vitamin D deficiency in European adolescents: the HELENA study. J. Nutr. Sci. Vitaminol. (Tokyo) 59(3), 161-171 (2013).

28 Vupputuri MR, Goswami R, Gupta N, Ray D, Tandon N, Kumar N. Prevalence and functional significance of 25-hydroxyvitamin D deficiency and vitamin D receptor gene polymorphisms in Asian Indians. Am. J. Clin. Nutr. 83(6), 1411-1419 (2006).

29 Lee BK, Lee GS, Stewart WF et al. Associations of blood pressure and hypertension with lead dose measures and polymorphisms in the vitamin D receptor and deltaaminolevulinic acid dehydratase genes. Environ. Health Perspect. 109(4), 383-389 (2001).

30 Wang L, Chu A, Buring JE, Ridker PM, Chasman DI, Sesso HD. Common genetic variations in the vitamin D pathway in relation to blood pressure. Am. J. Hypertens. 27(11), 1387-1395 (2014).
31 Hamet P, Daignault-Gelinas M, Lambert J et al. Epidemiological evidence of an interaction between calcium and sodium intake impacting on blood pressure. A Montreal study. Am. J. Hypertens. 5(6 Pt 1), 378-385 (1992).

32 Jorde R, Bonaa KH. Calcium from dairy products, vitamin $\mathrm{D}$ intake, and blood pressure: the Tromso study. Am. J. Clin. Nutr. 71(6), 1530-1535 (2000).

33 Miller GD, DiRienzo DD, Reusser ME, McCarron DA. Benefits of dairy product consumption on blood pressure in humans: a summary of the biomedical literature. J. Am. Coll. Nutr. 19(Suppl. 2), 147S-164S (2000).

34 Sowers MR, Wallace RB, Lemke JH. The association of intakes of vitamin $\mathrm{D}$ and calcium with blood pressure among women. Am. J. Clin. Nutr. 42(1), 135-142 (1985).

35 Vaidya A, Sun B, Forman JP et al. The Fok1 vitamin D receptor gene polymorphism is associated with plasma renin activity in Caucasians. Clin. Endocrinol. (Oxf.) 74(6), 783-790 (2011).

36 Al-Daghri NM, Al-Attas OS, Alkharfy KM et al. Association of $V D R$-gene variants with factors related to the metabolic syndrome, Type 2 diabetes and vitamin D deficiency. Gene 542(2), 129-133 (2014).

- A relevant publication from the Middle East investigating the association of vitamin $\mathrm{D}$ receptor variants with factors of the metabolic syndrome, diabetes, and serum 25OHD levels in 570 Saudi individuals.

37 Grundberg E, Brandstrom H, Ribom EL, Ljunggren O, Mallmin H, Kindmark A. Genetic variation in the human vitamin $\mathrm{D}$ receptor is associated with muscle strength, fat mass and body weight in Swedish women. Eur. J. Endocrinol. 150 (3), 323-328 (2004).

38 Prabhakar P, Majumdar V, Kulkarni GB, Christopher R. Genetic variants of vitamin $\mathrm{D}$ receptor and susceptibility to ischemic stroke. Biochem Biophys Res Commun. 456(2), 631-636 (2015).

39 Laczmanski L, Milewicz A, Lwow F et al. Vitamin D receptor gene polymorphism and cardiovascular risk variables in elderly Polish subjects. Gynecol Endocrinol. 29(3), 268-272 (2013).

40 Zemel MB, Shi H, Greer B, Dirienzo D, Zemel PC. Regulation of adiposity by dietary calcium. FASEB J. 14(9), 1132-1138 (2000).

41 Cho HJ, Kang HC, Choi SA, Ju YC, Lee HS, Park HJ. The possible role of $\mathrm{Ca}^{2+}$ on the activation of microsomal triglyceride transfer protein in rat hepatocytes. Biol. Pharm. Bull. 28(8), 1418-1423 (2005).

42 Kamycheva E, Jorde R, Figenschau Y, Haug E. Insulin sensitivity in subjects with secondary hyperparathyroidism and the effect of a low serum 25-hydroxyvitamin D level on insulin sensitivity. J. Endocrinol. Invest. 30(2), 126-132 (2007).

43 Takiishi T, Gysemans C, Bouillon R, Mathieu C. Vitamin D and diabetes. Endocrinol. Metab. Clin. North Am. 39(2), 419-446, Table of contents (2010).

44 Malecki MT, Frey J, Moczulski D, Klupa T, Kozek E, Sieradzki J. Vitamin D receptor gene polymorphisms and association with Type 2 diabetes mellitus in a Polish 
population. Exp. Clin. Endocrinol. Diabetes 111(8), 505-509 (2003).

45 Ranjzad F, Mahban A, Shemirani AI et al. Influence of gene variants related to calcium homeostasis on biochemical parameters of women with polycystic ovary syndrome. J. Assist. Reprod. Genet. 28(3), 225-232 (2011).

46 Ranjzad F, Mahmoudi T, Irani Shemirani A et al. A common variant in the adiponectin gene and polycystic ovary syndrome risk. Mol. Biol. Rep. 39(3), 2313-2319 (2012)

47 Liel Y, Shany S, Smirnoff P, Schwartz B. Estrogen increases 1,25-dihydroxyvitamin $\mathrm{D}$ receptors expression and bioresponse in the rat duodenal mucosa. Endocrinology 140(1), 280-285 (1999)

48 National Center for Biotechnology Information. www.ncbi.nlm.nih.gov/ 